
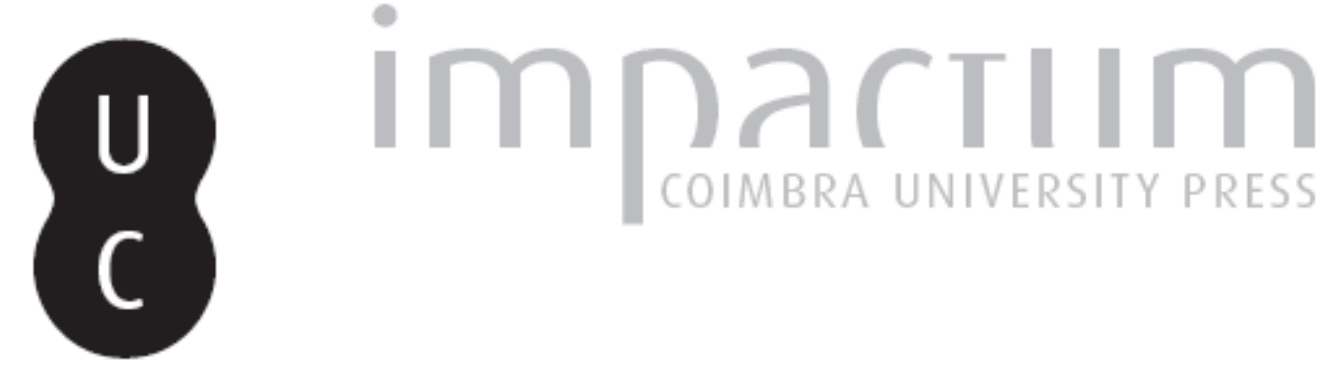

\title{
Ganharás o pão com o suor do teu rosto: imigrantes portugueses, padeiros e experiências políticas São Paulo/BR 1870-1945
}

Autor(es): $\quad$ Matos, Maria Izilda Santos de

Publicado por: Centro de História da Sociedade e da Cultura

URL persistente:

URI:http://hdl.handle.net/10316.2/39439

DOI:

DOI:http://dx.doi.org/10.14195/1645-2259_12_18

Accessed : $\quad$ 26-Apr-2023 08:13:31

A navegação consulta e descarregamento dos títulos inseridos nas Bibliotecas Digitais UC Digitalis, UC Pombalina e UC Impactum, pressupõem a aceitação plena e sem reservas dos Termos e Condições de Uso destas Bibliotecas Digitais, disponíveis em https://digitalis.uc.pt/pt-pt/termos.

Conforme exposto nos referidos Termos e Condições de Uso, o descarregamento de títulos de acesso restrito requer uma licença válida de autorização devendo o utilizador aceder ao(s) documento(s) a partir de um endereço de IP da instituição detentora da supramencionada licença.

Ao utilizador é apenas permitido o descarregamento para uso pessoal, pelo que o emprego do(s) título(s) descarregado(s) para outro fim, designadamente comercial, carece de autorização do respetivo autor ou editor da obra.

Na medida em que todas as obras da UC Digitalis se encontram protegidas pelo Código do Direito de Autor e Direitos Conexos e demais legislação aplicável, toda a cópia, parcial ou total, deste documento, nos casos em que é legalmente admitida, deverá conter ou fazer-se acompanhar por este aviso.

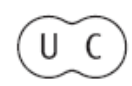


evista de História da Sociedade e da Cultura

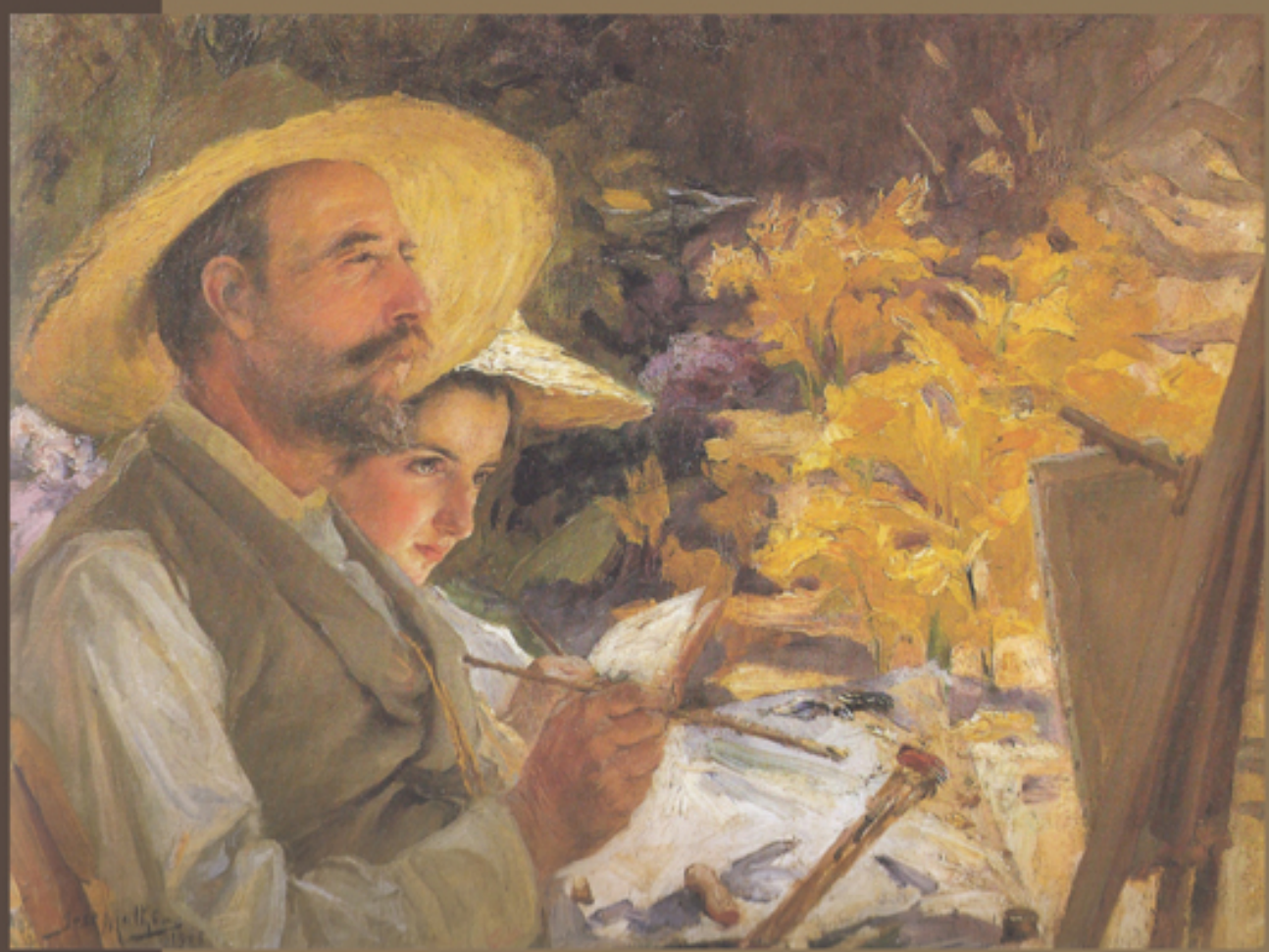

Centro de História da Sociedade e da Cultura Universidade de Coimbra 


\title{
Ganharás o pão com o suor do teu rosto: imigrantes portugueses, padeiros e experiências políticas São Paulo/BR 1870-1945*
}

\author{
Maria Izilda Santos de Matos** \\ Pontifícia Universidade Católica / São Paulo / Brasil \\ mismatos@pucsp.br \\ Texto recebido em /Text submitted on: 18/11/2011 \\ Texto aprovado em /Text approved on:12/02/2012
}

\section{Resumo/Abstract:}

Este artigo pretende ser uma contribuição para o estudo das experiências cotidianas de imigrantes portugueses na cidade de São Paulo, no período entre 1870 e 1945. A análise procurará recuperar a teia de relações cotidianas em sua dimensão da experiência no mundo dos negócios e do trabalho, recobrando as atividades de produção e comercialização do pão, observando a trama das conexões e tensões que se estabeleciam entre proprietários e trabalhadores nas padarias, na sua maioria de origem portuguesa. Privilegiando a documentação do DEOPS (Departamento Estadual de Ordem Política e Social), particularmente os prontuários, a proposta recupera enfrentamentos, formas de resistência, luta e greves que atingiram o setor da panificação.

This article is intended as a contribution to the study of the everyday experiences of immigrants in the city of Sao Paulo in the period between 1870 and 1945. The analysis will seek to recover the web of relationships in their everyday dimension of experience in business and labor, recovering the activities of production and marketing of bread, watching the fabric of connections and tensions that have established between owners and workers in bakeries in most of Portuguese's origin. Focusing the documentation DEOPS (State Department of Political and Social Order) of, particularly the charts, it recovers confrontations, forms of resistance, struggle and strikes that hit the sector of the bakery.

Palavras chave/Keywords:

Portugueses; Imigrantes; Padeiros; São Paulo; Cotidiano.

Portuguese; Immigrants; Bakers; São Paulo; Daily.

* O presente artigo faz parte do projeto: Portugueses: deslocamentos, experiências e cotidiano São Paulo Séculos XIX e XX, desenvolvido pela autora, com apoio do CNPq/Br.

** Doutorada em História (1991), Pós doutorado na Université Lumiere Lyon 2/França (1997), Professora titular da Pontifícia Universidade Católica de São Paulo.

Participa de vários projetos de pesquisa, é pesquisadora 1 do CNPq. Tem experiência na área de História, com ênfase em História do Brasil, atuando principalmente nos seguintes temas: imigração portuguesa, história e gênero, história e cidade. 
Este artigo focaliza as experiências de imigrantes portugueses na cidade de São Paulo/BR, no período entre 1870 e 1945. A análise procurará recuperar a teia de relações cotidianas na sua dimensão da experiência no mundo dos negócios e do trabalho, recobrando as atividades de produção e comercialização do pão, observando a trama das conexões e tensões que se estabeleciam entre proprietários e trabalhadores nas padarias, na sua maioria de origem portuguesa. Privilegiando uma ampla documentação, com destaque para os prontuários do Departamento Estadual de Ordem Política e Social (DEOPS/SP), a proposta recupera enfrentamentos, formas de resistência, lutas e greves que atingiram o setor da panificação.

\section{São Paulo: "a cidade que mais cresce no mundo"}

Na última década do século XIX, intensificou-se o processo de "modernização" do Brasil, com o final da escravidão e do regime monárquico, atrelado à crescente urbanização, imigração, migrações internas e industrialização, particularmente no sudeste do país. Estas mudanças provocaram, num curto espaço de tempo e em ritmo acelerado, transformações econômicas e sociais, gerando um novo perfil populacional, com considerável aumento demográfico e mudanças no universo do trabalho nas cidades e no campo.

A expansão urbana da cidade de São Paulo e sua consolidação como centro capitalista, integrador regional, mercado distribuidor e receptor de produtos e serviços foram fatores vinculados à expansão da produção cafeeira e a grande imigração. Neste processo, pode-se considerar como marco de mudança a inauguração da ferrovia Santos-Jundiaí (1863), que conectou São Paulo com o porto exportador de Santos e a com a zona cafeeira no interior do Estado. Os trilhos não só transportavam rápida e eficientemente o café, mas, também,

1 Apesar dos portugueses constituíram o grupo mais numeroso de imigrantes entrados no Brasil, só mais recentemente a temática tem instigado os pesquisadores, a maior parte dos estudos concentra-se no Rio de Janeiro. Apenas, nos últimos anos que apareceram trabalhos que investigam a presença dos lusos em São Paulo. Entre outras obras, ver: MATOS, M. Izilda Santos de Cotidiano e Cultura, Bauru, 2002; PASCAL, M. Aparecida. Portugueses em São Paulo. SP: Expressão e Arte, 2005; FREITAS, Sonia M. Presença Portuguesa em São Paulo, SP: Imprensa Oficial, 2006; MATOS, M. Izilda Santos de, e alli. Deslocamentos \& Histórias: os portugueses. Bauru/Porto, EDUSC/CEPESE, 2008. 
possibilitaram a chegada de uma massa de imigrantes, além de trazer de várias partes do mundo, particularmente da Europa, toda uma gama de produtos e influências, gerando e dinamizando um "vetor modernizador".

De acordo com o censo do ano de 1872, quando a cidade já sentia as conseqüências do surto cafeeiro, sua população era de 31.385 pessoas, elevando-se para 64.934 habitantes, em 1890. No começo do século XX, São Paulo assumiu seu destino de metrópole, sob o influxo do crescimento industrial, comercial e financeiro, em 1900, totalizava 239.820 habitantes, em vinte anos este número mais do que dobrou, atingindo a cifra de 579.033. Entre 1920 e 1940, a população novamente duplicou, saltando para 1.326.261 moradores. Em 1934, totalizavam 287.690 estrangeiros $^{3}$ (destes 79.465 portugueses) $)^{4}$, constituindo-se num mosaico diversificado de grupos étnicos e de seus descendentes, que, juntamente com os migrantes do interior do estado e de outras regiões do país, conviviam numa multiplicidade de culturas, tradições e sotaques. ${ }^{5}$

O florescimento da cidade tornou-a um pólo de atração para os imigrantes. Alguns vieram diretamente para a cidade e outros, após uma rápida passagem pela lavoura, migravam à procura de melhores perspectivas, novas oportunidades e na busca da realização de seus sonhos. Novos territórios se constituíam e passaram a receber as marcas dos grupos que ali se instalaram: os italianos no bairro do Bexiga, os japoneses na Liberdade, os judeus no Bom Retiro, os sírio-libaneses na Vinte e Cinco de Março, os portugueses em Santana e no Sumaré além de distribuídos em toda a cidade, em os redutos mais ocultos dos negros na Barra Funda e Casa Verde.

Os recém-chegados ${ }^{6}$ procuravam arranjar ocupações nas atividades urbanas, no setor fabril, comercial e de serviços, nas obras públicas e

2 ELIAS, Norbert. O processo civilizador. Rio de Janeiro: Jorge Zahar, 1994.

3 Censo Estadual de 1934.

4 ARAÚJO, Oscar Egídio de. Enquistamentos étnicos. In: Revista do Arquivo Municipal. vol. LXV, março de 1940.

5 Apesar das restrições na política imigratória a partir de 1930, presentes na Lei dos $2 / 3$ (decreto 19.482 de 12/12/1930) que garantia a cota de $2 / 3$ de trabalhadores brasileiros natos em todas as categorias profissionais. Na mesma década a medida foi relativizada pela Resolução 34 do Conselho de Imigração e Colonização (22/04/1939) que revogou qualquer restrição numérica as entradas de portugueses.

${ }^{6}$ Cabe destacar, que não houve um único padrão de deslocamento dos grupos familiares, muitos imigrantes eram chefes de família e vieram bem antes de seus familiares, que ficaram 
particulares. Porém, eles enfrentavam as dificuldades de um cotidiano com alta concentração de trabalhadores, excedendo largamente as necessidades do mercado e aviltando os salários. Difundiram-se múltiplas formas de atividades temporárias e domiciliares, subemprego, emprego flutuante, ampliando, assim, uma população que garantia a sua sobrevivência na base das ocupações casuais, às custas de improvisação de expedientes variados, eventuais e incertos, desenvolvendo experiências cumulativas de improvisação. ${ }^{7}$

O aumento da população com a chegada continua dos imigrantes gerou novos hábitos, gostos e práticas alimentares, que se tornaram mais variadas com a diversificação dos produtos oferecidos, ampliando as oportunidades para as atividades comerciais de abastecimento. Entre as diferentes categorias de vendedores ambulantes, que retiravam sua sobrevivência do comércio nas ruas, os imigrantes portugueses se encaixaram entre aqueles que ofereciam gêneros de abastecimento fundamentais à rotina doméstica, comercializados em pequenas quantidades que eram renovadas dia a dia. Utilizando-se de carrocinhas de madeiras, eles comercializavam verduras, frutas, flores, ovos e aves, carnes e peixes, leite e também pão.

Alguns recém-chegados começaram como ambulantes, mas, com muito empenho, trabalho e poupança, conseguiam se estabelecer em pequenos negócios; outros graças a seus tinos comerciais ascenderam à posição de comerciante, partindo daí para a diversificação de seus interesses. ${ }^{8}$

aguardando; outros vieram ainda quando crianças ou jovens, sem a família nuclear; em outros casos, a família nuclear veio junta, mas em alguns deles não permaneceram unidas no novo contexto ou nunca se encontraram e/ou não voltaram a se constituir DEMARTINI, Zeila Brito Fabri. Imigração, Família e Educação. In: Anais do V Congresso Luso-brasileiro de História da Educação. Évora: 2003, p. 3.

7 MATOS, Maria Izilda Santos de. Cotidiano e Cultura. São Paulo: EDUSC, 2002.

8 Entre 1910 e 1914 ocorreu um aumento considerável da imigração lusitana para São Paulo, com alterações nas suas caracterizadas de até então individual, masculina e temporária, tornando-se tendencialmente familiar e permanente. Estes imigrantes se destacam nas atividades comerciais. No atacado, os portugueses se estabeleceram no comércio do café, trigo, arroz, milho, batatas e cebolas, na importação e exportação de gêneros alimentícios, em especial vinhos, azeites e conservas, também no setor têxtil, fios, tecidos e artefatos de tecidos e vestuário. Os comerciantes portugueses eram a maioria entre os estrangeiros, superior aos sírio-libaneses e italianos. Censo de 1950- São Paulo, Nacionalidade dos proprietários e sócios de firmas individuais e sociedade de pessoas do comércio varejista segundo gênero de comércio. 


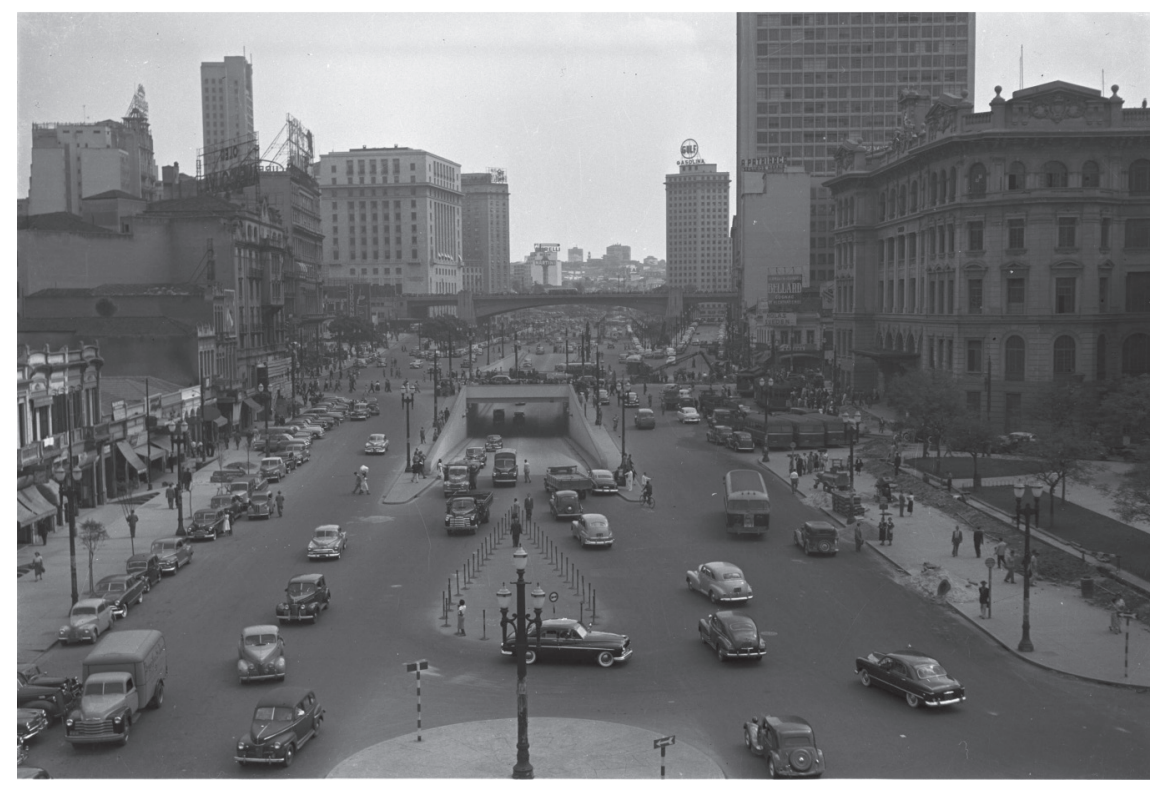

Os imigrantes portugueses se destacaram principalmente no comércio a retalho, se estabeleceram em negócios de pequeno e médio porte, na maioria unidades familiares: alfaiatarias, lojas de roupas, tecidos, armarinhos e miudezas, ferragens, louças, vidros, nos setores de serviços e alimentício. Procurando trabalhar com um custo operacional mínimo, eles aproveitavam o quarto da frente de suas próprias casas para constituírem pequenos armazéns de secos e molhados, açougues, adegas, quitanda de frutas e legumes, vendas e botequins.

Entrecruzando o público e o privado, o negócio e o lar, a família trabalhava duramente no balcão. Os poucos auxiliares eram, em geral, também portugueses, que se colocavam sob a tutela de conterrâneos, instituíram-se um sistema de redes de chamada. Dessa forma, estabeleceram negócios variados, como: quitandas, mercearias, leiterias, açougues, bares, cafés, botequins, restaurantes, pastelarias, tabernas, também nos hotéis, pensões e casas de cômodos, com ou sem o fornecimento de refeições, e particularmente as padarias e confeitarias. Alguns destes estabelecimentos eram mais simples, outros mais sofisticados com mesinhas, lustres, cristais, espelhos, visando reproduzir um estilo europeu além de tornarem-se aconchegantes e chiques, sendo freqüentes as referências nos anúncios da imprensa. 
Nas confeitarias e doceiras, serviam doces, cremes, chás, chocolates e sorvetes, algumas se tornaram pontos de encontro e se sofisticaram. Os restaurantes que se fizeram notar desde a década de 1850, se expandiram depois dos anos de 1870, e particularmente nos inícios do século XX, quando se tornou mais freqüentes às refeições fora de casa (especialmente o almoço), devido às distancias entre o trabalho e a casa.

Neste período, surgiram restaurantes de diferentes tipos, alguns ofereciam refeições mais simples, e outros, mais sofisticadas. Através dos cardápios divulgados nos anúncios de jornais, pode-se observar a presença de pratos regionais, nacionais e estrangeiros. A influência estrangeira foi crescente, particularmente, a dos menus franceses e do modelo de servir a "table ronde", com cardápio definido e preço fixo por pessoa. A presença dos imigrantes com seus gostos, práticas e sabores levou a diversificação do setor, com destaque inicial para os italianos, mas se fizeram presentes às marcas dos portugueses, espanhóis e de outras nacionalidades. ${ }^{9}$

Estrangeiros em São Paulo

\begin{tabular}{|c|r|r|r|c|}
\hline Anos & Total Geral & Portugueses & \multicolumn{1}{c|}{ Italianos } & Espanhóis \\
\hline $1885-09$ & 1.059 .199 & 134.594 & 744.244 & 180.361 \\
\hline $1910-34$ & 654.637 & 263.063 & 187.558 & 204.016 \\
\hline $1935-59$ & 311.987 & 156.536 & 90.130 & 65.321 \\
\hline $1960-61$ & 31.665 & 14.982 & 4.144 & 12.539 \\
\hline Total & 2.057 .488 & 569.175 & 1.026 .076 & 462.237 \\
\hline
\end{tabular}

Fonte: Departamento de Imigração e Colonização. São Paulo: 1962. p. 44.

\section{Com a mão na massa: fazer o pão}

Em São Paulo, até a segunda metade do século XIX, as mulheres eram as principais responsáveis pela preparação do pão, que era produzido majoritariamente com milho e mandioca. Elas se ocuparam das tarefas

9 SILVA, Siwla Helena. Restaurant à moda de Paris: mudanças culturais e o surgimento do restaurante na cidade de São Paulo (1855-70). Dissertação (Mestrado em história), PUC-SP: 2007. 
de preparar a farinha, peneirar, fazer a massa e assar os pães. ${ }^{10}$ Algumas trabalhavam para outras mulheres, donas dos fornos e da matéria-prima e vendiam nas ruas e/ou entregavam nos domicílios.

A partir da segunda metade do século XIX, as transformações na cidade foram influenciadas pelos imigrantes ${ }^{11}$, que entre os novos gostos e práticas difundiram o uso do trigo (da farinha de trigo), particularmente, para a elaboração dos pães. Estabeleceram-se padarias que viabilizavam uma produção maior, sistematizada e cotidiana adequada ao crescimento da demanda. Neste processo, a atividade feminina foi substituída pelo trabalho de homens, particularmente solteiros, de forma que as mulheres passaram a não mais atuar nos espaços de preparação do pão. ${ }^{12}$

Os responsáveis iniciais pela expansão da panificação na cidade foram os imigrantes italianos. As padarias, na maioria dos casos, eram empresas familiares, destacaram-se a Santa Tereza (1872), Ayrosa (1888) e Popular (1890, da família Di Cunto). Elas produziam os chamados "pães caseiros" com fermentação natural, o que os tornava mais saborosos nos dias seguintes, sendo assim, a maioria dos clientes adquiriam o produto para 2 ou 3 dias, o que facilitava a organização dos horários e o descanso semanal.

O setor da panificação se difundiu com a ampliação da influência das chamadas padarias e confeitarias francesas e da preferência pelo pão do tipo

${ }^{10}$ Referências simbólicas e culturais constituíram significados sobre o pão, sua presença simboliza fartura, abundância, enquanto sua falta identifica carência, fome e miséria. O cristianismo identifica o pão ao corpo divino, além de clamar pelas bênçãos do "pão nosso de cada dia". Lutas e movimentos sociais foram constituídos clamando pelo pão, como denúncia da situação de miséria a qual estavam submetidos certos setores sociais. Tanto no Brasil quanto na Europa, o preparo e consumo do pão acompanhavam rituais e cerimônias, usava-se fazer cruzes nas massas, rezar salmos para fazê-los crescer e ficarem macios e bonitos. "O pão suscita o respeito mais arcaico, é quase sagrado. Joga-lo ao chão, pisa-lo é visto como sacrilégio... O pão é memorial." CERTEAU, Michel de. A invenção do Cotidiano: II. Petrópolis: Vozes, 1996, p. 133-34.

${ }^{11}$ Cozinhar é transmissão de um saber geracional, de tradições, vinculada à memória familiar e da comunidade de origem, envolve gestos ritos e códigos herdados e repetidos. $\mathrm{Na}$ preparação do alimento precisava-se orçar a disponibilidade do recurso, observar na compra a qualidade dos ingredientes, calcular o tempo de preparo e as porções para não ter desperdício ou falta. CERTEAU, Michel de. A invenção do Cotidiano: II. Petrópolis: Vozes, 1996.

${ }^{12}$ Só em 1920 apareceram as primeiras padarias mecanizadas. Em São Paulo, havia um total de 8.860 padarias em 1950 e mais de 13 mil nos anos 60. Na década de 1970, passaram para 70 mil, com um consumo de mais de um milhão de toneladas de pão por ano. 
francês. A partir de 1860, nos jornais da capital paulista o número de anúncios de padarias e de procura de padeiros cresceu, permitindo avaliar como a panificação ganhara um incremento inusitado. Os anúncios ocupavam várias páginas, revelando as mudanças de hábitos, o desenvolvimento comercial da cidade e o aumento de um contingente de imigrantes que se envolveram na atividade de preparo e venda do pão.

Os anúncios na imprensa permitem observar toda a variedade de pães que era oferecida, com destaque para o pão francês, mas também para a bisnaga, o pão de família, o pão de Paris, o pão-de-rala (feito com centeio e milho), o pão de leite (com ovos e açúcar), o meleças, o saloio ${ }^{13}$, o quartado (mistura de farinhas de trigo, centeio, cevada e milho) e outras qualidades. Somava-se um grande sortimento de roscas, tranças, biscoitos, sequilhos e bolachas. As padarias (misto de mercearias) também ofereciam café moído e leite puro, sendo que de todos os produtos "afiança-se a boa qualidade e os preços cômodos".

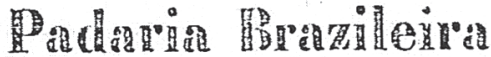 RUA DO ROZARIO NN. 30}

N'oste eslobelecimonto novamento preparado coin limpeza continua-so a fabricar pâis de tolos as qualidalos, biscoutos, reseas, soquilhos, bnlaxas, biscoulos doces para servir ao chà, de dito. rontes qualidades. Yendo-so ossucar refinado, arrobado, o as libras, suporior qualidado de manteigos, vellas do cohno, o composiçāo, vinhos, sorveja ingleza preta e bránea, conservas licores de diversas qualidades, refreseos de tomarindos, orxala, dita em pó, grozeille, xarope de vinagro, dito de limāo, dito do gơma o outros, ludo por pregos muito inferiores aos actunes; o moilns outros generos de molbalos. Apromtão-so re. ceitas dos mesmos para fóra corn promptidâo, nas quacs so fiz differença nos preças conformo a porção, lanto nos molhados, como nos objeclos Jo massas, o assucor. Aliança<so a boo qualidade llos generos, os quaes nẫo agradando ao compros dor acceita-so restituindo-se sou importo.

O estabelecimonto está as ordens para quem quizer olsservar so o trabaltho é, ou nān failo com limpeza, poulendo ser visto a qualquer hora di dia ou da naito.

Fonte: Correio Paulistano, 25 de setembro de 1862.

${ }^{13}$ Este tipo de pão é feito de uma variedade de trigo e por uma forma especial de preparo, difundida nos arrabaldes de Lisboa. 
Com a propagação do uso do fermento biológico tornou mais ágil a forma de preparar o pão, permitindo a produção de várias fornadas diárias, com pão quente a toda hora. Algumas padarias ofereciam pão quente desde as 5 horas até as 9 horas da manhã, de tarde entre as 3 e 5 horas e das 7 até as 9 horas, além de se proporem a aprontar "encomendas para fora com toda a brevidade" para festas, casamentos, batizados, etc.

Estas práticas foram difundidas especialmente nas padarias de propriedade dos portugueses, que também inovaram a organização do negócio com a incorporação de vários sócios, os quais se revezavam em diferentes turnos, garantindo, assim, o funcionamento contínuo dos estabelecimentos nos 7 dias por semana e por quase 20 horas diárias. Neste setor, os portugueses se destacaram e integravam todas as etapas da produção do pão: donos de padarias, fornecedores de lenha e carvão para os fornos, trabalhadores como masseiros, forneiros, carvoeiros e entregadores.

Com o crescimento do setor, em 1915, os proprietários de padarias constituíram a União dos Proprietários de Padarias de São Paulo. O Estatuto Social foi aprovado na Assembléia Geral, ocorrida em 9 de Março, quando além de discutirem os assuntos pertinentes à estruturação da entidade, foram levantadas as questões que mais incomodavam os panificadores naquele momento. ${ }^{14}$ Sendo proposta a constituição de um registro de fregueses (buscando selecionar os bons pagadores) e um cadastro de empregados. A organização do cadastro de empregados pretendia ordenar informações quanto ao caráter, assiduidade e engajamento político, buscando direcionar os patrões na hora das contratações, identificando os "indesejáveis", inclusive levando a demissão, suspensão, multas e ridicularização.

O cadastro de empregados foi uma das primeiras disposições e buscava o registro de todos os demitidos das padarias, os proprietários comunicavam os nomes dos trabalhadores e os motivos de sua demissão, que eram divulgados pelas padarias, impedindo que ele encontrasse novo emprego. Os motivos mais citados eram falta de assiduidade e roubo, todavia a acusação de roubo poderia, ser utilizada para encobrir demissões relacionadas às atividades

${ }^{14}$ PERISSINI, Nilmara Cristina. Da União à Fundação: a história da panificação em São Paulo. São Paulo: Mundial, 2005. 
políticas, apesar de se encontrarem nas listas alguns operários declarados como "agitadores", "insubordinados" e "subversivos".

Exemplar foi o caso do padeiro Eleutério do Nascimento preso em setembro de 1934, sendo identificado pela polícia como um "perigoso ladrão"15. Porém, o noticiário do jornal A Plebe esclarecia a situação, destacando as prisões arbitrárias de trabalhadores e sindicalistas. Neste caso, a prisão ocorreu justamente durante a greve dos padeiros de 1934, capitaneada pelo Sindicato dos Padeiros, sendo Eleutério um dos líderes do movimento:

Conhecido como é esse companheiro entre os trabalhadores de sua classe, de cujo Sindicato vem sendo, de há muito, honesto colaborador, essa notícia provocou a mais justa repulsa [...] não é ladrão, mas honesto trabalhador padeiro. ${ }^{16}$

A União dos Proprietários de Padarias também articulou os próprios proprietários em torno das questões do abastecimento da farinha de trigo, especificamente, nos momentos de carestia do produto, como durante a Primeira Grande Guerra (1914-18). Outra questão que envolvia os proprietários foi a dos enfrentamentos com a Diretoria de Higiene Municipal que, entre suas funções, buscava organizar e fiscalizar a higiene no local durante o processo de produção do pão.

Neste momento, as ações do órgão público visavam normatizar a localização das cocheiras junto às padarias. Cotidianamente, a distribuição do pão era feita por entregadores em carrinhos, na maioria de tração animal (cavalos e burros), desta forma, atendia-se a freguesia que morava mais longe, ou que por comodidade, gostava de ter o pão entregue em sua casa. Depois das entregas, os carrinhos e os animais eram guardados em cocheiras instaladas junto às padarias, gerando polêmica com os órgãos de higiene, os quais propunham que estas cocheiras fossem instaladas fora do perímetro urbano, afastadas das padarias.

Segundo os proprietários esta medida dificultaria o serviço de entregas. Após vários protestos dos proprietários e de sua entidade, as cocheiras foram mantidas junto às padarias, mas com a condição de serem azulejadas e conservadas sobre rigorosas normas de higiene e limpeza.

\footnotetext{
${ }^{15}$ Prontuário DEOPS-SP, $\mathrm{n}^{\circ} 1899$ - Eleutério Nascimento.

${ }^{16}$ A Plebe, $\mathrm{n}^{\circ} 72,29 / 09 / 1934$.
} 
A União dos Proprietários de Padarias de São Paulo encerrou suas funções em 1917, voltando a se constituir em 1920, com acirramentos das tensões entre patrões e empregados. Em 1922, a Câmara Municipal de São Paulo procurou regulamentar dias e horários de funcionamento das padarias, de forma a garantir o descanso semanal dos empregados. ${ }^{17}$

Frente à questão, a União dos Padeiros (órgão de representação dos empregados) iniciou a conversação com os patrões, destacando entre suas reivindicações a extinção do trabalho noturno com a concentração da fabricação do pão no período diurno. Os proprietários consideram a proposta impraticável, pois inviabilizaria as entregas matutinas que eram muito lucrativas para as padarias. Quanto ao descanso semanal, ficou estabelecida a segunda-feira, mas muitas padarias mantiveram sua produção neste dia.

As tensões cresciam, principalmente, frente à fiscalização da prefeitura, já que em alguns casos os fiscais eram mais rigorosos e em outros mais flexíveis. A associação patronal entrou com representação junto a Câmara Municipal de São Paulo buscando extinguir a lei.

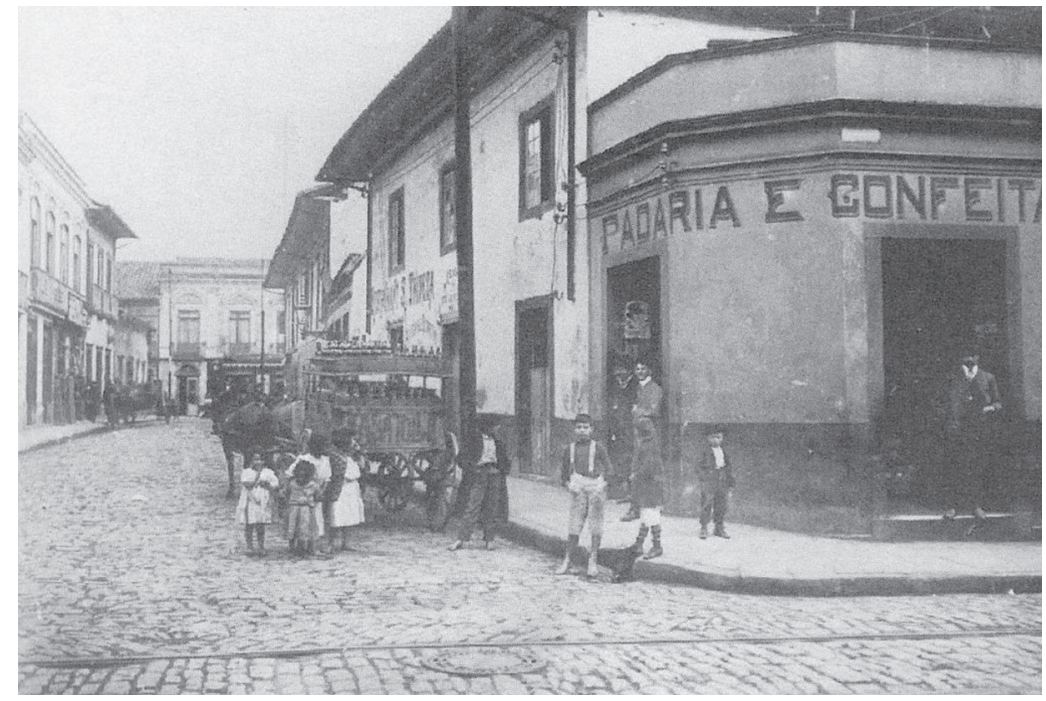

Padaria de português.

Acervo do Memorial do Imigrante de São Paulo

${ }^{17}$ Através da lei $\mathrm{n}^{\mathrm{0}} 2.503$ (sancionada em dezembro de 1922), também se passou a exigir a regulamentação dos entregadores de pão perante os órgãos de fiscalização pública com exame para obtenção da carteira de cocheiro (artigo 71, ato n 1426 de abril/1920). 
Em 1925, novamente, a União dos Proprietários foi encerrada, voltando a se constituir em 1928, como Associação dos Proprietários de Padarias de São Paulo, centrando suas ações nas questões com seus empregados e com a prefeitura, como: quanto ao descanso semanal, horários de trabalho, higiene nas cocheiras e no processo de fabricação do pão. Assim, novos impasses se constituíram com a Diretoria de Higiene que buscava normatizar o acondicionamento do pão, que deveria ser embrulhado imediatamente após a saída do forno e não mais colocados e sacos, cestos ou tabuleiros. ${ }^{18}$

\section{O pão que o diabo amassou}

O fazer o pão exigia conhecimento e habilidades profissionais, subentendendo um processo com diferentes etapas e hierarquias. Inicialmente o trigo era peneirado dentro de uma masseira de madeira, em separado fazia-se o fermento, em seguida misturavam-se os ingredientes que deveriam ser amassados "a muque" (utilizando-se a força física) ${ }^{19}$, só com experiência - através do toque - que se adquiria o conhecimento do ponto ideal da massa.

A massa já pronta descansava, dependendo da temperatura esse processo era mais lento ou mais rápido, posteriormente ela era cortada, pesada, sovada, para depois se modelar os pães, que eram colocados em tábuas aprontando-os para logo serem levados ao forno, na hora de colocar no forno era que o corte do pão era dado.

O forno redondo de barro e tijolos não possuía termômetros, estando sob o controle do padeiro. Nas padarias maiores havia o forneiro, que devia preparar o forno (limpava, colocava a lenha, ascendia o fogo) e pela experiência sentir a temperatura, sabendo o momento exato de colocar e retirar o pão. Os pães eram colocados no forno com cuidado e habilidade, com a palheta posicionava-os de um lado e retirava-os prontos de outro,

${ }^{18}$ Nos anos 30, também foi criado o Sindicato dos Industriais de Panificação e Confeitaria de São Paulo reconhecido pelo Ministério do Trabalho, dessa forma o setor patronal adquiriu dupla representação.

${ }_{19}$ As masseiras elétricas começaram a ser utilizadas em meados da década de 1920, mas sua difusão foi lenta e parcial, sua incorporação mais generalizada, ocorreu a partir dos anos 40 . 
estas ações exigiam atenção e prontidão para evitar que os pães ficassem crus ou torrados. ${ }^{20}$

A jornada de trabalho nestes estabelecimentos era longa, começava às 18 horas com o preparo da massa e se estendia por toda a noite, já que às 4:30 horas o pão deveria estar pronto para a venda e para as entregas à freguesia. Já às 7 horas, começavam os preparativos para o pão da tarde, quando os instrumentos e o local eram limpos enquanto o pão estava sendo assado. O descanso era das 12 horas às 18 horas, contudo, este horário não era fixo podendo ocorrer variações.

Os padeiros também ajudavam no balcão e realizavam as entregas, mas em outros casos a "freguesia era feita" pelo entregador, que iniciava o trabalho por volta das 4:30 horas da madrugada e terminava por volta das 6:30 horas. Ele saia com um cesto grande e entregava em armazéns, bares e domicílios. Alguns entregadores comercializavam em carrocinhas (puxadas a burro ou cavalo, posteriormente motorizadas) que lhe permitia servir a uma clientela mais distante.

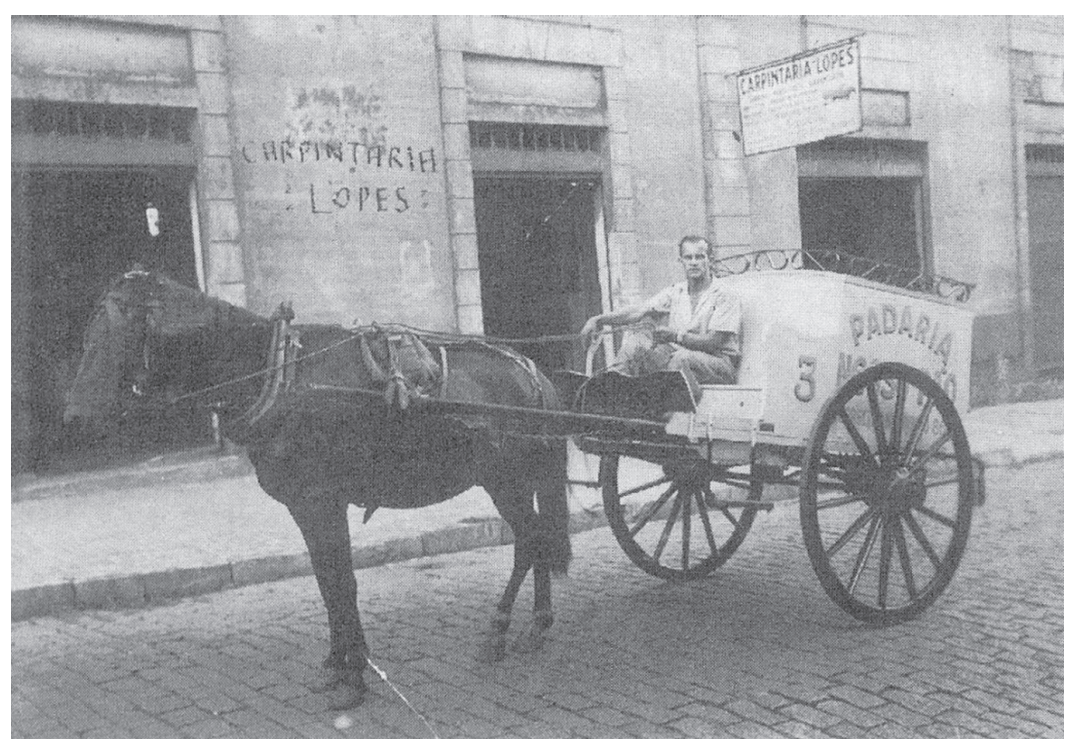

Entregador de pão

Acervo do Memorial do Imigrante de São Paulo

${ }^{20}$ FONTES, Edilza. O Pão nosso de cada dia. Belém: Paka-tatu, 2002. 
A freguesia era constituída por uma parceria entre o freguês e o padeiro/ entregador, o qual se empenhava em agradar e manter a clientela. ${ }^{21}$ As relações estabelecidas entre eles subentendiam solidariedade e cobranças, várias eram as exigências quanto à pontualidade de horário na entrega, ao tipo e qualidade do pão, às preferências (o pão mais torrado ou branquinho). Mesmo em momentos de dificuldades para a obtenção e controle sobre a farinha de trigo, o que poderia acarretar a perda de qualidade do pão, os padeiros se empenharam em servir a freguesia. $O$ pagamento era realizado aos sábados, mas tinha os que "acertavam" por quinzena e até mesmo por mês, logicamente, havia os atrasos e as dívidas acumuladas.

O pão tinha que ser feito todos os dias, sendo imperdoável a falta do padeiro e não havendo descanso, sábados, domingos ou feriados. Para além da jornada extensa e noturna, sem repouso e da falta de folgas, deve-se destacar que todas as etapas do processo de preparação do pão eram árduas e pesadas, com dispêndio de força para a preparação da massa, além das altas temperaturas do local de trabalho. A esta situação somava-se a insalubridade da função, que causava mal aos pulmões e aos olhos, doenças cardíacas e pulmonares, como tuberculose, asma e pneumonia, além de reumatismo, queimaduras e varizes.

Nesta atividade os ganhos eram parcos, alguns trabalhavam por anos sem receber nada a não ser a hospedagem e um prato de comida, mesmo para os mais gabaritados os pagamentos eram instáveis, eles poderiam ampliar ganhos com a venda do pão em domicílio.

A maior parte dos trabalhadores das padarias (homens solteiros) morava no local de trabalho, uma espécie de alojamento fornecido pelo proprietário, que também fornecia as refeições, o que facilitava aos recém chegados, pois os livrava das despesas com acomodações, transporte e alimentação. Contudo, os cômodos eram precários, sujos, mal arejados e a comida não podia ser considerada boa. Cabe observar que essas ações eram estratégias patronais de controle sobre o cotidiano e o horário de trabalho, garantia de assiduidade, pontualidade e possibilidade de extensão da jornada, buscando disciplina, criando dependência e outros vínculos.

${ }^{21}$ A compra ou repasse de uma freguesia era uma responsabilidade e deveria ser precedida de uma apresentação, pois o freguês mantinha fidelidade ao seu padeiro. 
O dono da padaria - o português - escolhia o padeiro e seus ajudantes, fornecia o local e a matéria-prima e cobrava produção. Buscava o controle, através do número de pães que cada saca de trigo produzia, mas esse número dependia da qualidade da farinha e das habilidades do padeiro. Também, controlava-se a produção através da vigilância do processo de trabalho, chegavam a trancar a sala da padaria restringindo a saída dos padeiros.

\section{Aprendia-se a trabalhar - trabalhando}

Aprendia-se a ser padeiro na própria padaria. Os jovens principiantes observavam o processo de preparação do pão atuando como auxiliares, alguns entravam com 8 ou 10 anos, eram filhos e parentes ou amigos do próprio padeiro ou ainda do dono da padaria. O processo de aprendizagem era lento, incluindo submeter-se a várias atividades: peneirar o carvão, rachar lenha, colocar lenha no forno, limpeza do forno, carregar os sacos de farinha, enrolar os panos, ajudar a fazer a massa, limpar e varrer a padaria, atender no balcão, fazer entregas, entre outros. Eram atividades que demandavam força (agüentar peso, carregar cestos com 60 pães), conhecer as redondezas e a freguesia, enfrentar a longa jornada, entre outras

Dependendo das habilidades e dedicação poderia passar para amassador, padeiro e forneiro.

Quando cheguei fui trabalhar com meu irmão, era caixeiro, era tudo [...] ajudava a amassar levantava às 2 de manhã, ajudava no balcão e a distribuir o pão. Morava na padaria $[\ldots]^{22}$

Reforçando esse depoimento, os anúncios de jornais deixavam clara a preferência:

Caixeiro precisa-se de um pequeno de 14 a 16 anos, português, com prática em padaria, que seja trabalhador, obediente e honesto. Exige-se referências. Tratar à $[\ldots] .{ }^{23}$

${ }^{22}$ PADRÃO, Antonio. Depoimento [12/04/2004]. São Paulo. Entrevista fornecida a autora. Na época, o entrevistado de origem portuguesa tinha 82 anos.

${ }^{23}$ Diário de São Paulo, São Paulo: data 1926. 
Ao chegarem, os imigrantes contavam com o apoio dos parentes ou conterrâneos já radicados, sendo prática mandar chamar parentes, conhecidos, jovens da aldeia para ajudar nos negócios, eram considerados de confiança. Mas cabe lembrar que, em alguns casos, a ajuda se transforma em exploração do trabalho desses conterrâneos mais jovens e pobres, desprotegidos em ambiente desconhecido, assim, exploração e paternalismo coexistiam nas casas comerciais, oficinas e nos lares.

A necessidade das crianças desde cedo se engajarem no trabalho, quer seja nas fábricas, oficinas e nas ruas, além de ser fruto das necessidades dos imigrantes pobres, também era vista como possibilidade da obtenção de um ofício que lhes garantisse um futuro mais promissor.

Os aprendizes, padeirinhos e caixeirinhos trabalhavam em troca de casa e comida, numa rotina que incluía limpeza da padaria, atendimento dos fregueses nos balcões, estoques, carregar e entregar mercadorias. Buscando formar trabalhadores produtivos, obedientes e dóceis, patrões e mestres impunham práticas austeras, medidas destinadas a inculcar nas crianças hábitos de trabalho, hierarquias e disciplina, o que incluía castigos físicos e punições. Assim, as condições de trabalho e de vida durante o aprendizado compreendiam a prática do castigo físico, dentre outras práticas vexatórias e punições aviltantes e violentas, como dormir debaixo dos balcões ou no ladrilho da padaria, tornando as fugas freqüentes.

Nos processos crimes e nos jornais liam-se notícias como a do menor Alfredo Júlio Machado, português de 11 anos de idade, que foi se queixar ao delegado de polícia por ter sido espancado pelo seu "amo" José Rodrigues Tavares, também português. ${ }^{24}$

Em geral, estes jovens trabalhadores permaneciam nos domicílios e negócios dos parentes, arcando com os afazeres muitas vezes sem nada receber, outras vezes parcamente remunerados ou submetendo-se a pagamentos incertos, contudo, estas condições eram estratégias de sobrevivência e sendo os únicos recursos possíveis em certas ocasiões.

\footnotetext{
${ }^{24}$ Diário de São Paulo, São Paulo: 06 de dezembro de 1886
} 


\section{Ganhar o pão com o suor do próprio rosto}

Em 1877, depois de organizar um "levante" que paralisou as padarias do porto de Santos (1876), João de Mattos rumou para São Paulo, onde preparou outro "levante" bem sucedido, reunindo os trabalhadores de 12 padarias da cidade. Fugindo da polícia paulista, em 1878, ele chegou ao Rio de Janeiro para organizar ações similares e na Corte criou o Bloco de Combate dos Empregados em Padarias, que tinha como lema "Pelo pão e pela liberdade" 25 . Outras associações, cooperativas e ligas foram constituídas com a sua participação, bem como, a edição de periódico da categoria como O Panificador (desde 1898/RJ) ou O Trabalhador Padeiro (SP).

Desde os primórdios da expansão das padarias na cidade de São Paulo, as questões em torno das condições de trabalho e da entrega dos pães geravam embates entre patrões e trabalhadores, produzindo ações de resistência e luta constantes durante o século XX. Nos anos 20, a União dos Padeiros que coordenava a categoria, encabeçou a greve (1924), que tinha como motivo a reivindicação da troca de alojamento e comida por melhores salários.

Experiências de luta da categoria culminaram na institucionalização de um sindicato em 16 de novembro de 1930 (Sindicato dos Manipuladores de Pão, Confeiteiros e Similares de São Paulo), que nasceu sob o signo da organização e combatividade.

A questão do descanso semanal dos padeiros em São Paulo, iniciada em 1922, arrastou-se até 1931, quando o benefício foi estabelecido por lei. ${ }^{26}$ AAssociação dos Proprietários de Padarias de São Paulo, insatisfeita, tentou impedir a execução da medida, entrando com pedido de inconstitucionalidade, mas a sua legalidade foi reconhecida. Contudo, na prática a situação era outra, a resistência dos patrões em implementar a medida era constante e anos depois esta questão ainda se fazia presente da pauta dos grevistas.

Em 1931, o Sindicato dos Manipuladores de Pão, afiliado a Federação Operária de São Paulo (FOSP), mobilizou-se em prol do descanso dominical.

${ }^{25}$ MATTOS, Marcelo Badaró. Experiências comuns: escravizados e livres no processo de formação da classe trabalhadora no Brasil. In: Anais do XXIV Simpósio Nacional de História. São Leopoldo: 2007.

${ }^{26}$ Lei n $^{\circ} 2.563 / 31$ do município de São Paulo; lei federal no ${ }^{\circ}$ 9.770/31, sobre organização sindical dos masseiros e forneiros de padaria. 
Militantes anarquistas como Francisco Cianci, Herminio Marcos e Natalino Rodrigues foram registrados como indivíduos sempre presentes em assembléias e conferências da categoria.

Atingindo diretamente o abastecimento da cidade, em 1932, eclodiu uma nova greve da categoria que durou um mês. Nesta ocasião, as reivindicações se concentravam no aumento salarial, nos horários das atividades, no trabalho noturno e nas folgas semanais. Apesar dos inconvenientes da falta de pão, o Sindicato procurou o apoio da população, valendo-se da imprensa, divulgando no Diário de São Paulo, que eles defendiam a fiscalização sanitária e higiene nos locais de trabalho, além das demandas da classe. ${ }^{27}$

Durante a paralisação, a liderança sofreu forte repressão policial, principalmente depois dos embates entre os mais engajados e os colegas que não aderiram à paralisação, sendo enviados policiais para garantir o funcionamento de padarias. Vários padeiros foram presos, entre eles, o líder anarquista Natalino Rodrigues. ${ }^{28}$
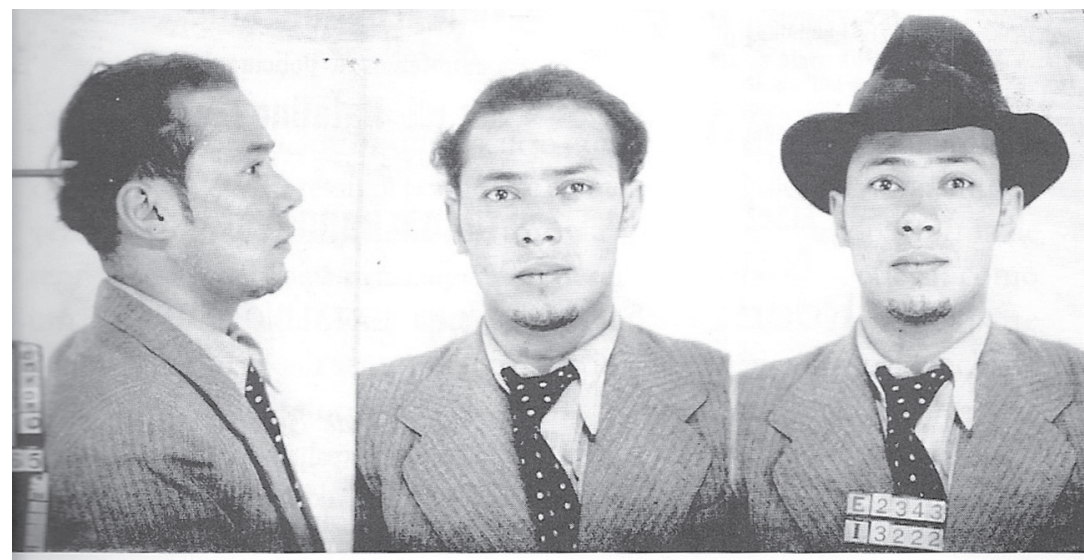

Fotos do anarquista Nathalino Rodrigues, identificado em 1932. Laboratório Técnico de Fotografia do Gabinete de Investigação. Pront 1286 Nathalino Rodrigues. DEOPS/SP. DAESP.

Fotos do Anarquista

\footnotetext{
${ }^{27}$ Prontuário DEOPS-SP, no 868 - Associação dos Manipuladores de Pão e Confeiteiros e Similares de São Paulo.

${ }^{28}$ Prontuário DEOPS-SP, no 1286 - Nathalino Rodrigues.
} 
Já as paralisações de 1934/35 se constituíram frente às recusas da categoria ao registro e identificação via carteira de trabalho, associada às novas medidas decretadas pelo Ministério do Trabalho. O Sindicato se colocava contrário ao registro, visto como um novo elemento de controle dos trabalhadores. Eles acusavam o Departamento Estadual do Trabalho de forçar a identificação, fazendo com que os patrões exigissem dos empregados fotografias e fichas, com o fim de pôr em prática encargos e identificar dos trabalhadores mais engajados. ${ }^{29}$ Esta resistência pode também ser explicada pela elevada presença de estrangeiros na categoria, sugerindo uma ameaça, já que entre os portugueses, a quantidade de imigrantes irregulares era sempre alta. ${ }^{30}$

As reuniões e as lideranças do Sindicato dos Manipuladores de Pão, Confeiteiros e similares (com sede no prédio da Rua Quintino Bocaiúva, $n^{\circ} 80$ ) encontravam-se sob permanente vigilância policial. O que levou a novas prisões de vários líderes envolvidos, como: Natalino Rodrigues considerado "um de seus principais dirigentes e organizadores da greve, agitador e provocador de distúrbios". ${ }^{31}$ Também Eleutério do Nascimento...

(português-padeiro) era sócio do Sindicato dos Manipuladores de Pão e Anexos Confeiteiros. Foi preso em maio de 1934, acusado de ter alvejado Antonio Conceição, que participante de uma greve. Em setembro do mesmo ano, Eleutério foi novamente preso, acusado de agitador. Em 1935, foi preso por duas vezes, sendo a ultima por suspeita de roubo. ${ }^{32}$

As ações provocaram o fechamento pela polícia do Sindicato dos Manipuladores de Pão, suspendendo temporariamente a circulação do o jornal O Trabalhador Padeiro. ${ }^{33}$

${ }^{29}$ PARRA, Lúcia Silva. Combates pela liberdade: o movimento anarquista sob a vigilância do DEOSP (1924-45). São Paulo: Arquivo Estado/Imprensa Oficial do Estado, 2003.

${ }^{30}$ SILVA, Rodrigo Rosa da. Imprimindo a Resistência: A Imprensa Anarquista e a Repressão Política em São Paulo (1930 -1945). Dissertação (Mestrado em História), UNICAMP: 2005.

${ }^{31}$ Prontuário DEOPS-SP, no 1286 - Nathalino Rodrigues.

${ }^{32}$ Prontuário DEOPS-SP, $\mathrm{n}^{\circ} 1899$ - Eleutério do Nascimento.

${ }_{33}$ José Rocca Orozco foi preso em 19 de fevereiro de 1937, acusado de anarquismo. Foi redator do jornal $O$ Trabalhador Padeiro. Recebia jornais de sindicatos e associações de classe da Espanha. Prontuário DEOPS-SP, n 2393. Prontuário DEOPS-SP, $\mathrm{n}^{\circ} 868$ Associação dos Manipuladores de Pão e Confeiteiros e Similares de São Paulo 
Uma nova greve eclodiu em 1937. As reivindicações dos padeiros incluíam várias demandas: cumprimento da lei das oito horas de trabalho, salário mínimo e férias, pagamento em dinheiro do que recebiam em comida e alojamento (equivalente a aumento de salário de 120 réis, correspondente à pensão e ao dormitório), direito ao café e a um quilo de pão para cada operário. Destaca-se que

[...] a greve foi iniciada por alguns manipuladores de pão que não podiam suportar a alimentação que lhes era fornecida pelos patrões; que ordenado, quase geral, é de cento e oitenta mil reis mensais, com direito a comer e a dormir na padarias, que os descontentes pleitearam uma diferença para mais de cento e vinte mil reis mensais para a pensão $[\ldots]^{34}$

Frente à forte resistência dos proprietários, a greve teve inicio em 21 de agosto atingindo várias padarias. ${ }^{35} \mathrm{O}$ movimento ganhou novas adesões e no dia seguinte a maior parte das padarias não funcionou.

Só abriram as portas os poucos que fizeram acordo, em separado, com os seus masseiros. Mas a produção dos raros estabelecimentos em atividade era insuficiente para abastecer $[\ldots] .{ }^{36}$

A posição patronal se manteve, as demandas dos padeiros eram consideradas descabidas e eles identificados como agitadores. Em resposta, os patrões iniciaram um locaute fechando as padarias e revidando com a demissão de mais de 400 empregados de 41 padarias. ${ }^{37}$ Os sindicalistas replicaram denunciando que donos de padaria estavam criando pretextos, para elevar o preço do pão.

${ }^{34}$ Prontuário DEOPS-SP, no 4265 - José Soares de Azevedo. Percebe-se se que o DEOPS estava atento às atividades do Sindicato dos Manipuladores, tanto que certa vez foi dissolvida uma assembléia por falta de autorização necessária para a sua realização. A partir de então, todas pautas de reuniões eram entregues ao DEOPS com antecedência. Prontuário DEOPS-SP, $n^{\circ} 868$ - Associação dos Manipuladores de Pão e Confeiteiros e Similares de São Paulo.

${ }^{35}$ Prontuário DEOPS-SP, n $^{\circ} 4.162$ - Associação dos Proprietários de Padaria de São Paulo.

${ }^{36}$ MENDES, José Sacchetta Ramos. Fornada de conflitos: portugueses na greve dos padeiros de 1937. In: Metrópole das Utopias. No prelo.

37 "Sobre a Greve dos Padeiros". O Estado de S. Paulo. São Paulo, 24/08/1937, p. 10. Apud MENDES, José Sacchetta Ramos. Fornada de conflitos: portugueses na greve dos padeiros de 1937. In: Op.cit. 
Apesar dos aconselhamentos iniciais da Associação dos Proprietários sobre a conveniência de negociar com as lideranças dos trabalhadores, foram poucos os estabelecimentos que aceitaram as reivindicações, fechando acordo com seus empregados. Na maioria das padarias não foi possível um entendimento. Com o recrudescimento e o acirramento das ações, abandonaram-se as negociações, os patrões endureceram a posição e os poderes públicos aumentaram a vigilância policial levando a prisão de vários envolvidos.

Outras duas categorias do setor: carvoeiros e entregadores em domicílio, envolveram-se na questão. Ficando os carvoeiros alinhados com os donos de padaria, enquanto os entregadores de pão declararam greve em apoio ao movimento dos padeiros.

Na madrugada de quarta-feira, em vários bairros da cidade, ocorreram brigas e detenções de grevistas, em geral motivadas pelo confronto de piqueteiros com entregadores que insistiam em sair com suas carroças para o trabalho. Como descrevia o Dr. Miranda Amaral, Delegado de plantão:

Ilmo Sr. Dr. Superintendente da ordem política e social da capital Comunico-vos que durante o meu plantão das 12 horas de ontem às 12 horas de hoje, nesta superintendência verificamos.

Às 4 hrs recebi uma comunicação do guarda de serviço na R. Barão de Campinas esquina com a Alameda Glete, avisando que um grupo de entregadores de pão se encontrava de fronte da Padaria e confeitaria Inglesa, situada na mesma rua, a espera da saída das carrocinhas de pão, afim de atacarem os entregadores. Transportei-me ao local e fiz remover os agressores para esta superintendência. Apreendi um revolver em poder de Mauricio Gambá e uma pistola em poder de Manoel Gonçalves de Oliveira, empregados da padaria em questão que utilizavam as referidas armas em defesa própria.

Às 5 hrs no Alto da Lapa os grevista Manoel Carvalho, Manoel de Sá Pinto, Jalmires Pinho Ribeiro e Antonio Sá Pinto tentaram agredir os entregadores de pão Joaquim Fernandes e Manoel Antonio Quintas, depois de se apoderar de todo o pão que traziam, os mesmos declararam que iam entrega-lo a Gazeta para distribuição aos pobres. Fiz recolhe-los ao xadrez desta superintendência.

Às 6 hrs, na rua do Glicério, foram detidos e recolhidos ao xadrez os indivíduos Alpheu de Souza e Manoel de Almeida Cardoso por terem sido encontrados distribuindo boletins cujos exemplares passo a 
suas mãos. Junto a comunicação do Sr. comandante da guarnição desta superintendência.

Miranda Amaral Delegado de plantão. 26/8/1937. ${ }^{38}$

Pode-se observar que os envolvidos foram presos, como o entregador lusitano José Joaquim da Silva, quando tentava convencer seus colegas a não trabalhar..$^{39}$ Observam-se outras ocorrências como a agressão ao fura-greve, também português, Manoel Antunes Quintas, que fora atacado por outros entregadores, que tomaram seus pães e os distribuíram aos pobres. ${ }^{40}$ $\mathrm{O}$ acirramento da situação levou a ação policial, que buscou colocar um soldado armado para cada carrocinha de entrega em atividade.

O Sindicato dos Proprietários divulgou uma proposta: aumento para 870 réis (como teto da categoria), alguns estabelecimentos acataram a sugestão e fizeram acordo com seus empregados, voltando às atividades normais; mas a maioria dos patrões recusou a indicação e por temor a represálias, suspenderam o serviço de distribuição e mantiveram fechadas as padarias.

[...] mas os patrões não se conformaram e promoveram a greve pagando os vencimentos dos manipuladores e proibindo-os de trabalhar; que, com a falta de pão, os vendedores viram-se prejudicados e procuraram defender seus interesses; que na realidade os maiores prejudicados foram os vendedores que nada tinham com a questão dos manipuladores; que o declarante e seus companheiros que foram detidos ontem na rua Conselheiro Nébias, não praticaram, nem tinham intenção de praticarem quaisquer violências contra os referidos vendedores. ${ }^{41}$

Frente a tal situação, durante a segunda semana da greve, a diretoria da Liga dos Entregadores de Pão retirou seu apoio aos padeiros, buscando uma posição de neutralidade e até se apresentou disposta a intermediar o conflito. Mas havia entregadores que se mantinham favoráveis ao movimento, gerando novos enfrentamentos.

Manoel Soares declarou que ele e seus companheiros, Antonio Gonçalves Grillo, José Joaquim da Silva, Antonio dos Santos, José

${ }^{38}$ Prontuário DEOPS-SP, no 4483 26/08/1937

39 Prontuário DEOPS-SP, $\mathrm{n}^{\circ} .4169$ - José Joaquim da Silva.

${ }^{40}$ Prontuário DEOPS-SP, $\mathrm{n}^{\circ} 4297$ - Manoel Antunes Quintas. Relatório de Investigação. São Paulo: 26/08/1937.

${ }^{41}$ Prontuário DEOPS-SP, no 4265 - José Soares de Azevedo. 
Soares de Azevedo, Rogério Augusto Venâncio e Avelino Costa foram detidos na madrugada de ontem, pelas quatro horas. Na Alameda Glete e, sendo que alguns foram detidos na Rua Conselheiro Nébias; que o declarante não conhece os quatro queixosos acerca do fato, nada podendo dizer sobre os mesmos; que o declarante ouviu que os queixosos ao serem interpelados pelos companheiros do declarante quiseram fazer uso de armas de fogo, porém o declarante não viu esta arma; que os companheiros, primeiros referidos queriam convencer os quatro queixosos de que não deviam voltar ao trabalho afim de não prejudicar a greve dos vendedores e manipuladores de pão; porém a policia interveio no momento oportuno [...] que além de prejuízo que causariam a greve, prejudicariam também os colegas tomando-lhes a freguesia $[\ldots]^{42}$

As padarias buscaram contratar novos entregadores, que diferentemente dos padeiros, tinham uma função que poderia ser exercida por quem soubesse conduzir a carrocinha. A distribuição do pão tendeu a ser normalizada, os grevistas foram ficando isolados, gradativamente, o movimento foi se esvaziando e os padeiros buscaram se acertar com os patrões. Esta greve dos padeiros durou 12 dias. Nos meses subseqüentes instaurou-se o Estado Novo (1937-45), as ações de repressão do DEOPS se efetivam na capital paulista, este processo novamente os padeiros e entregadores de origem lusitana foram atingidos.

Em 1939, as autoridades policiais alegavam que o Sindicato dos Manipuladores de Pão era ilegal, por não ter sido ainda registrado pelo Ministério do Trabalho. Para que o sindicato fosse legalizado deveria comprovar boa conduta de seus membros. Fazendo com que, em 1940, o Sindicato dos Manipuladores de Pão retirasse da porta de sua sede a placa de "Sindicato" e a substituíram por de "Associação". ${ }^{43}$

${ }^{42}$ Prontuários DEOPS-SP, nº 4212 - Manoel Soares; 4274 - Rogério Augusto Venâncio; 4188 - Manoel de Sá Pinto; 4273 - Manoel de Almeida Cardoso; 4265 - José Soares de Azevedo; 4304 - Manoel de Carvalho. Todos de origem lusitana e referente ao ano de 1937.

${ }^{43}$ Prontuário DEOPS-SP, no 868 - Associação dos Manipuladores de Pão e Confeiteiros e Similares de São Paulo. 


\section{Nos papéis da repressão}

Não se habita impunemente em outro país, não se vive no seio de uma outra sociedade, de uma outra economia em um outro mundo, em suma, sem que algo permaneça desta presença, sem que se sofra mais ou menos intensa e profundamente, conforme as modalidades de contato, os domínios, as experiências e as sensibilidades individuais, por vezes, mesmo não se dando conta delas e, outras vezes, estando plenamente consciente dos efeitos. ${ }^{44}$

A trajetória histórica de homens e mulheres imigrantes, particularmente portugueses, envolveu uma heterogeneidade de atividades com destaque para as comerciais. Alguns obtiveram rendas relativas com probabilidade de ascensão social, outros sobreviveram através de estratégia e improvisações cotidianas.

No setor comercial os imigrantes portugueses identificaram as possibilidades da realização do sonho da imigração. Da mesma forma que em outras cidades, pode-se destacar que:

Falar da imigração portuguesa significa mergulhar em um espaço privilegiado: o do comércio, destino mistificado para todos aqueles que acalentavam sonhos de promoção social no além-mar. Nesse espaço significava, ainda, privilegiar dois atores principais do drama cotidiano: negociante e o caixeiro, figuras emblemáticas que se fizeram presentes no espaço urbano ao longo de todo o processo de urbanização. A medida que expandiu a malha urbana, o comércio português a varejo acompanhou esse crescimento tornando o português da esquina referência obrigatória $[\ldots]{ }^{45}$

O balcão da padaria era também palco das tensões do cotidiano, envolvendo cobranças, atrasos e recusa no pagamento das contas consideradas abusivas, hostilidades, brigas, provocações, insultos, xingamentos e manifestações de anti-lusitanismo.

${ }^{44}$ SAYAD, A. O retorno: elemento constitutivo da condição do imigrante. Travessia Revista do Migrante. vol. 13, São Paulo, jan/2000, p. 14.

${ }^{45}$ MENEZES, Lená Medeiros “Jovens portugueses: Histórias de sucesso, histórias de trabalho, histórias de fracasso". In GOMES, Ângela de C. (org.) Histórias de imigrantes e de imigração no Rio de Janeiro. RJ, Sette Letras, 2000, p. 164. 
$\mathrm{Na}$ trama destas relações se destacam os vínculos de nacionalidade e memórias em comum, a ajuda aos conterrâneos na hora da chegada, hospedagem e empréstimos, também o estabelecimento de relações de confiança (gerência e até sociedade nos negócios), favores e dependências. Mas, principalmente, de tensões, ao final era o dono da padaria - o português - que escolhia o padeiro e seus ajudantes (muitos também portugueses), sempre buscando manter o controle e a sujeição dos trabalhadores.

Os prontuários do DEOPS possibilitam observar os embates entre trabalhadores e proprietários, também os conflitos intra-étnicos, alguns que culminaram em greves e enfrentamentos, com a presença da polícia e identificação e prisão dos mais atuantes. 